\title{
ラット自由行動下における煩筋，舌筋， 咬筋活動の筋電図学的研究
}

\author{
井ノ森 巳賀子 \\ 九州歯科大学大学院歯学研究科歯科麻醉学専攻 (指導 : 西 正勝教授) \\ 九州歯科大学生理学講座 (指導：中原 敏教授)
}

平成 4 年 12 月 22 日受理

\author{
EMG Activities of Buccinator, Tongue and Masseter Muscles \\ in the Freely-moving Rat \\ Mikako Inomori
}

\begin{abstract}
Department of Dental Anesthesiology (Director: Prof. Masakatsu Nishi)
Department of Physiology (Director: Prof. Satoshi Nakahara)

Kyushu Dental College, Kitakyushu, Japan
\end{abstract}

A Mammal stops sucking and starts chewing in the growing process. Buccinator muscle, which is one of the facial muscles, mainly works during sucking. Masseter muscle, which is one of the masticatory muscles, mainly works during chewing. Tongue muscle works to help sucking and chewing. I studied electromyographically the buccinator, tongue and masseter muscles in freely-moving rats, with a view to finding the characteristics and the relations of those muscles' activities during feeding, grooming, exploring and resting.

Bipolar electromyographic electrodes of $50 \mu \mathrm{m}$ (in diameter) stainless steel wire coated with Teflon ${ }^{\circledR}$ were placed subcutaneously on the center of buccinator, tongue and masseter muscles, and led to a connector pedestal on the rat's head. EMGs of the buccinator muscle and the tongue muscle were recorded simultaneously, and so were those of the buccinator muscle and the masseter muscle.

The results were as follows;

1. The rhythmical discharges of the buccinator, tongue and masseter muscles appeared during feeding, grooming, exploring and resting.

2. The rhythmical bursts during feeding of the buccinator muscle had relation to that of the tongue muscle, and also to that of the masseter muscle. The cycles of those were about $220 \mathrm{msec}$ in all of them.

3. The time lag of the rhythmical bursts during feeding between the buccinator muscle and the tongue muscle was about $100 \mathrm{msec}$. That between the buccinator muscle and the masseter muscle was about $10 \mathrm{msec}$.

4. The duration of the rhythmical bursts during feeding was the longest in the tongue muscle's activities, and was almost the same between the buccinator and the masseter muscle 
activities.

5. The integrated EMG activities of the buccinator muscle were almost the same in the cases except resting. The integrated EMG activities of the tongue muscle in grooming and exploring were about half of that in feeding, that in resting, about the one fifth of that in feeding. The integrated EMG activities of the masseter muscle in grooming, exploring and resting was smaller than that in feeding.

Key words: EMG/Buccinator muscle/Tongue muscle/Masseter muscle/Freely-moving rat

\section{緒言}

咀嚼運動は主働筋である咀嚼筋と補助的な役割をむつ 顔面筋や舌筋の精妙な協力によって行われるリズミカル な運動である．また，吸啜運動む顔面筋や舌筋を中心之 した筋群によってリズミカルに行われる運動である，今 日まで咀嚼運動や吸啜運動におけるこれらの咀礵筋之顔 面筋の活動について様々な研究が行われているが，これ らの筋のリズムの比較やリズム形成器との関係について 論述したものは少ない.

煩筋は顔面筋のひとつであり，吸啜運動においては舌 筋と共に主役をなしている．この煩筋は成体で咀嚼時に 口腔前庭の食物を移動させる働きを持ち，谷津ら（1988

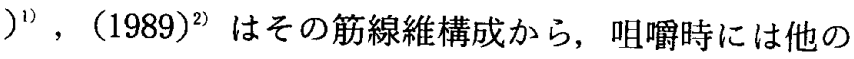
顔面筋と比べかなり機能負担が高いと報告している。一 方, 舌は咀礵運動において食物を上下歯列間に運び゙, 食塊を歯列弓に保持するという補助的な役割を果するの で,5)，いずれも非常に精妙な運動が要求されることか ら, 多数の筋によって構成されている ${ }^{68)}$. また, 咀礵運 動や吸啜運動における舌運動は，呾䂃筋や顔面筋之同様 に末梢からの感覚入力の影響を受けて複雑な運動を行っ ているものと考えられる゙-11.

本実験では, 咀骝筋の中でも強力な働きをむつ咬筋之 補助的に働く舌筋, また顔面筋の一つである煩筋がどの ように協調して働くかを調べる目的で, 摂食行動を始め とする諸行動時の筋電図を測定し検討した。

\section{研究方法}

実験動物には 27 匹の雄性，成体 Wistar 系ラットを 用いた。

実験動物は，煩筋之舌筋から筋電図を同時記録する煩 筋一舌筋群之, 煩筋と咬筋から筋電図を同時記録する煩 筋一咬筋群の二群に分けた。
エチルエーテル吸入および $6 \%$ 抱水クロラール水溶 液 $(4 \mathrm{ml} / \mathrm{kg})$ 腹腔内投与麻酔下で, ラット頭部正中線 上に切開線をいれ，頭皮および頭蓋骨骨膜を剝離した。 露出した頭蓋骨骨面に電極固定装置を歯科用セメントで 接着した。この電極固定装置から,テフロン被覆ステン レス撚り線（裸線径 $0.05 \mathrm{~mm}$, コート径 $0.225 \mathrm{~mm}$ ）を皮下 に走行させ, 先端距離を $1 \mathrm{~mm}$ とした双極誘導電極を煩筋 と舌筋，および煩筋と咬筋の組み合わせでそれぞれの筋 に固定した。

電極の固定位置は，Fig. 1 に示したように頓筋では その中央部, 舌筋では舌尖と舌臼㐘間隆起との中点で舌 の厚みの中央，咬筋では浅部咬筋中央部で，口角之耳介 の下端を結ぶ直線上に眼球外側部より垂線を降ろしたそ の交点とした。これらの測定部位はいずれも同側とし た.

なお，今回顔面筋の代表として煩筋を選んだが，これ はラットでは口輪筋の周囲に洞毛を動かす筋が多く，ロ 輪筋以外の筋電図が混入することが予想されたのに対 し，頰筋は顔面筋の中でも深層にあり，その中央部であ れば他の筋の筋電図が混入しないと考えたからである. また，咬筋と同時記録を行なってあ，煩筋と浅部咬筋之 の距離およびこれらの筋間にある煩骨の存在により, 㭌頁 筋の双極誘導電極では咬筋の筋電龱を導出しないと考え たからである.

電極固定後約 1 週間の回復期間をおき, 摂食行動, 毛 づくろい行動, 探查行動および安静時の筋電図を煩筋之 舌筋，および煩筋と咬筋の組み合わせで同時記録した。 なお，探查行動とは，本来動物が新しい場所に置かれた 場合，その場所を探るために起こす行動のこよである が, 本実験では摄食行動, 毛づくろい行動以外でラット がなんらかの行動をしていると観察された場合を探査行 動とした。また，ラットの体がほとんど動いていないと きを安静時とした。 
(1)

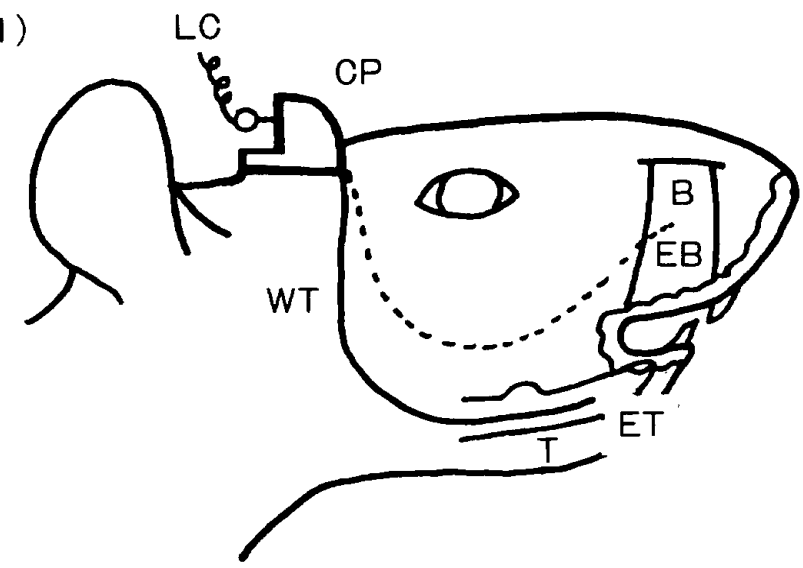

(2)

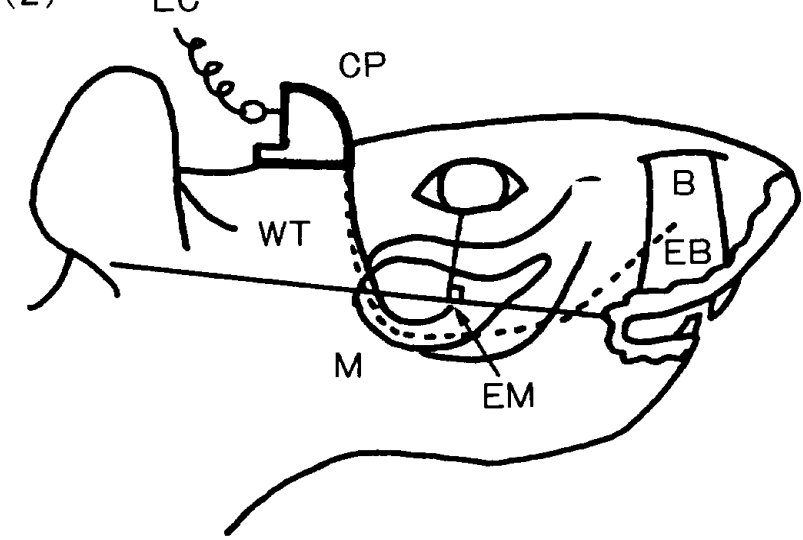

Fig. 1 Schema of recording electrodes.

A connector pedestal is fixed on the rat's head. (1); Experimental group of buccinator muscle and tongue muscle. (2); Experimental group of buccinator muscle and masseter muscle. $\mathrm{CP}$ : connector pedestal. EB, ET, EM : bipolar electrodes set to buccinator, tongue and masseter muscles. WT : wire coated with Teflon ${ }^{\circledR}$. LC : lead cords. $\mathrm{B}$ : buccinator muscle. $\mathrm{T}:$ tongue muscle. $\mathrm{M}$ : masseter muscle.

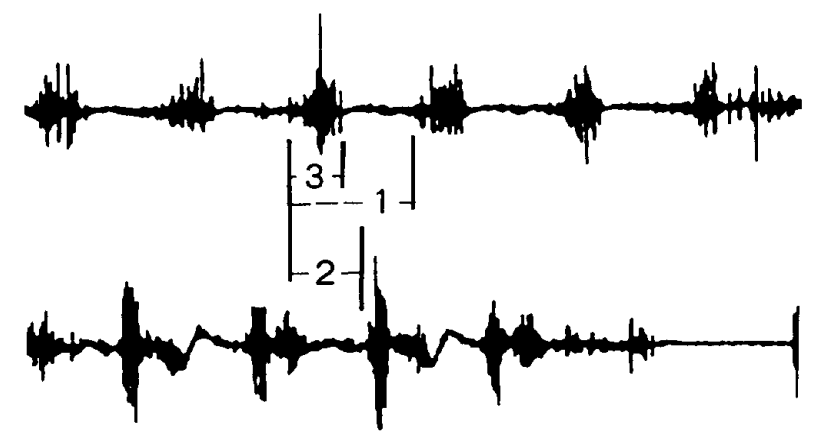

Fig. 2 Analysis on rhythmical bursts of muscle activities during chewing. $1:$ cycle. $2:$ time lag. 3 : duration.
筋電図測定は，エチルエーテル吸入麻酔下にラット頭 部の電極固定装置にリード線を接続し，床敷きを入れた プラスチック製ケージ（縦 $20 \mathrm{~cm}$, 横 $35 \mathrm{~cm}$, 高さ $30 \mathrm{~cm}$ ) に移し, 覚醒後, 飼育に使用している固形飼料 (CE2 ，クレア社）と給水瓶を置いて自由に掑取させながら 行った。

筋電図は, オッシロスコープで増幅した後, データレ コーダ（NFR-3000，ソニー社）に保存記録した。保存 記録したデータは，サーマルアレイレコーダ（WS-641 $\mathrm{G}$ ，日本光電社）を用いて再生記録した.

再生記録した筋電図は各行動ごとにその特徵を分類 し，煩筋一舌筋，煩筋一咬筋間の協調関係を検討した。 Fig. 2 に示したように摄食行動時の筋電図から，リズ ミカルな放電のサイクル，その放電の出現時間のずれ (以後位相差という), および放電持続時間を測定し， 煩筋一舌筋之煩筋一咬筋間の比較を行った．数値の算定に あたっては，各実験群とも200 個の放電を抜き取って 行った.

また，データレコーダの保存記録をミニポリグラフ （RM-6100, 日本光電社）を使用し, 積分アンプ（EI$610 \mathrm{G}$, 日本光電社）で処理後, その積分曲線を摃食行 動, 探查行動, 毛づくろい行動および安静時に分類し, それをむとに筋活動量を比較した。なお比較にあたって は, 各行動ごとに連続 5 秒間の積分値を無作為にそれぞ れ計 36 か所（計 180 秒間）拔き取り，筋活動量とした。 さらに摄食行動時の積分値の平均值を 100 として他の行 動時の積分值を換算し, その平均值と標準偏差をもとに 比較した。

\section{結 果}

\section{I . 筋電図}

\section{A. 摄食行動}

Fig. 3，4 は摃食行動時の筋電図の一例である．煩筋 一舌筋, および煩筋-咬筋のいずれにも対応したリズミカ ルな放電を認めた（図のF 1)。

咀嚼時の筋電図に示したれ印のように，切歯部で固形 飼料を咬断する際, 音が発生した.この切歯部咬断音発 生時にはいずれの筋むりズミカルな放電は消失し，咬筋 之舌筋では振幅の小さい放電が発生した。

摄食行動時には煩筋，舌筋，咬筋のいずれの筋電図に あ,リズミカルな放電が多く認められたが, 咀嚼終了後 にも舌筋，咬筋にはリズミカルな放電が，顂筋には持続 的な放電が認められる場合があった（F 2)。この時 ラットは咬合しながらあ顔を動かしたり，嗅いだりして 
$\mathrm{B}$

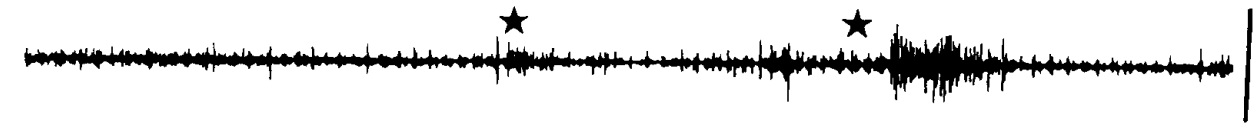

F1

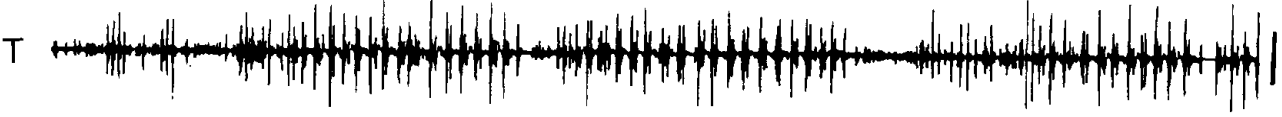

B

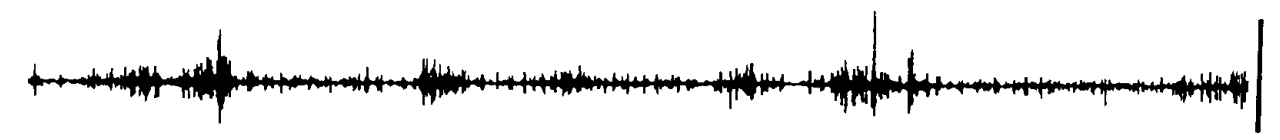

F2

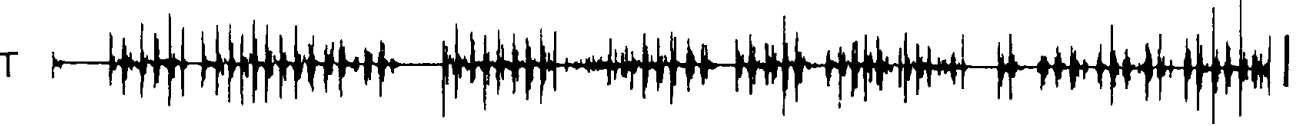

B

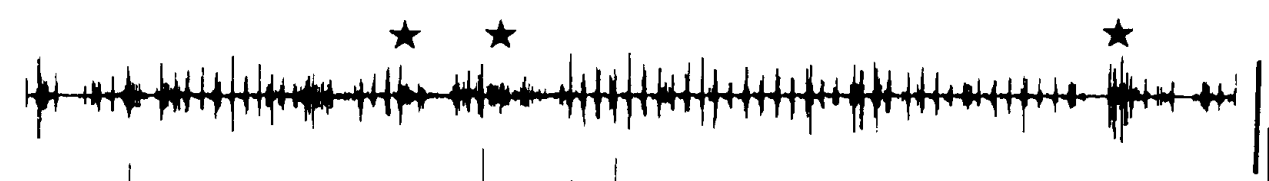

F1

M

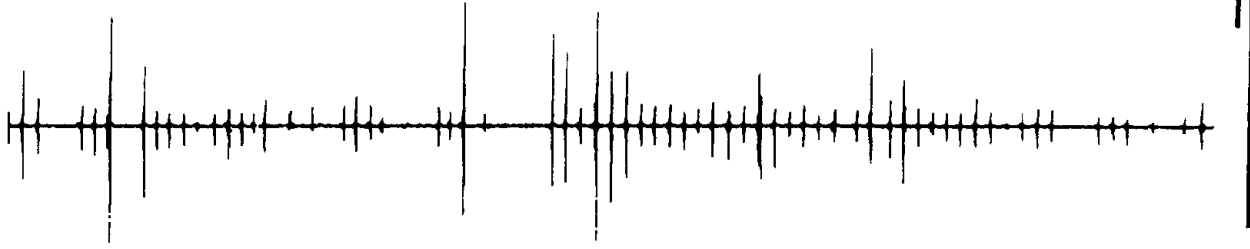

F2

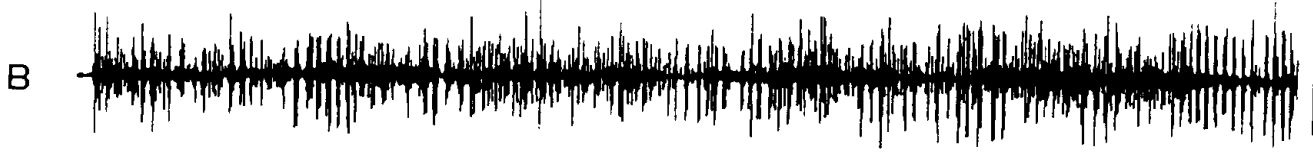

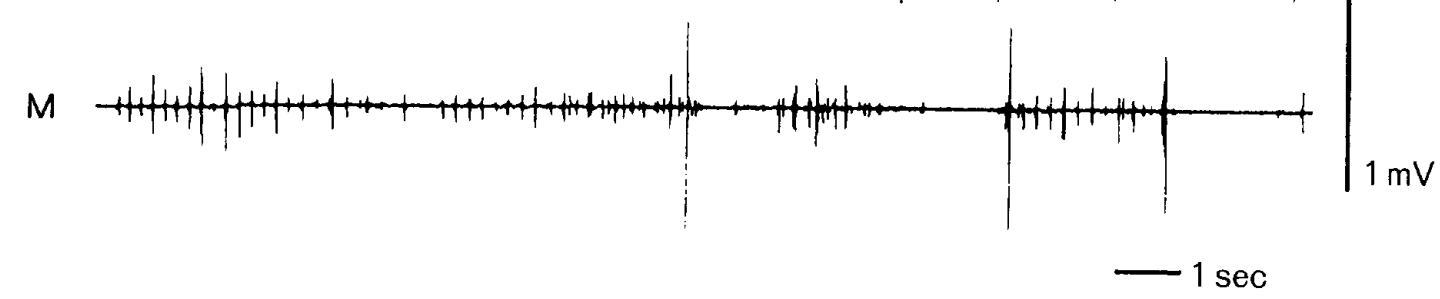

Fig. 3 EMG patterns during feeding.

Star marks $\star$ : the time that the biting sound by incisor has occurred in.

$F 1$ and $F 2$ indicate two types of the EMG pattern.

$\mathrm{B}$ : buccinator muscle. $\mathrm{T}$ : tongue muscle. $\mathrm{M}$ : masseter muscle.

おり, 後述の探査行動時の頓筋の筋電図と似たパターン になっていた。

リズミカルな放電のサイクルは Fig. 5 に示したよう
に頓筋では $221.5 \pm 11.1 \mathrm{msec}$ ，舌筋では $220.3 \pm 28.9$ msec, 咬筋では $222.5 \pm 29.8 \mathrm{msec}$ で平均值ではいずれ の筋もほぼ同じであった。 
B

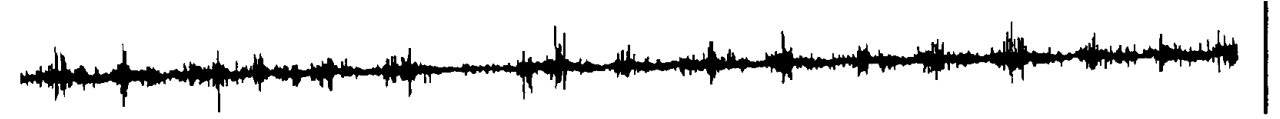

$\mathrm{T}$

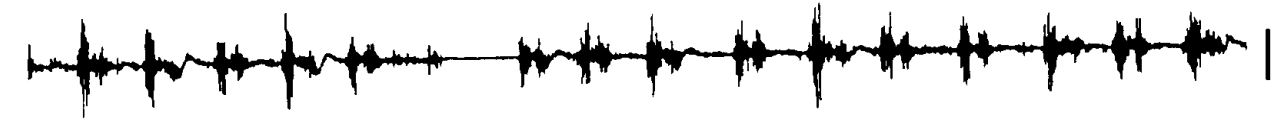

B
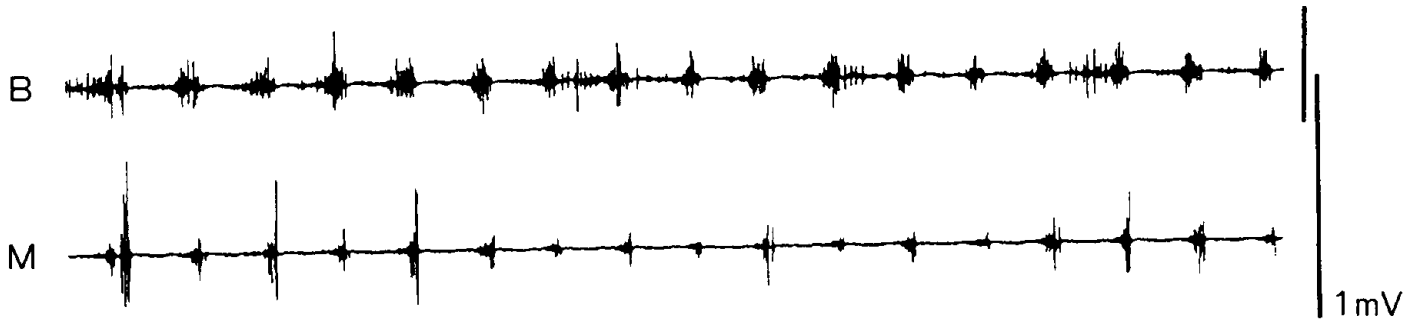

$1 \mathrm{sec}$

Fig. 4 Rhythmical discharge during chewing.

These traces are recorded by hastening the paper speed. Others are the same as Fig. 3.

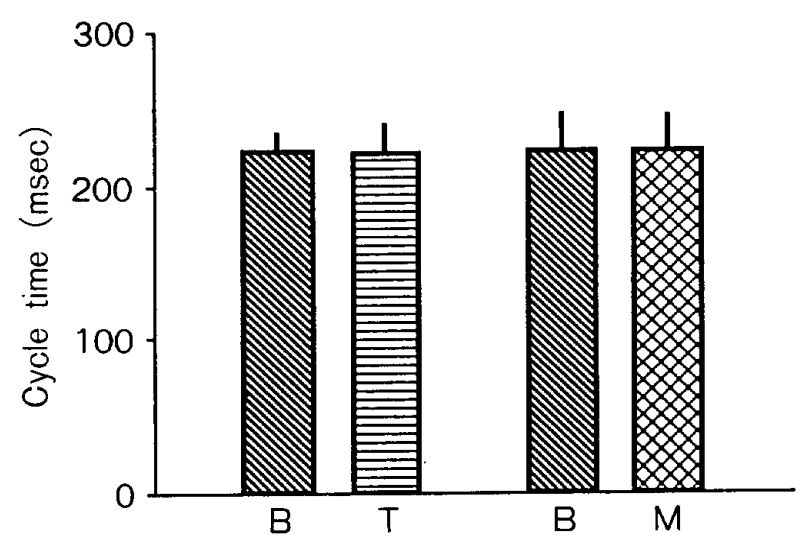

Fig. 5 Cycle time (mean \pm S. D.) of rhythmical bursts during chewing.

Others are the same as Fig. 3.

Fig. 6 にリズミカルな放電の位相差を示す．この位 相差は，煩筋一舌筋間では $102.6 \pm 31.1 \mathrm{msec}$ と前述の サイクルの約 $1 / 2$ であった（図の B-T）．煩筋一咬筋間

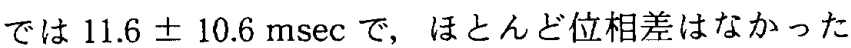
(B-M).

Fig. 7 にリズミカルな放電の持続時間を示す. 放電

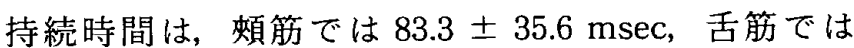
$120.6 \pm 22.2 \mathrm{msec}$ ，咬筋では $81.5 \pm 27.0 \mathrm{msec}$ で，舌 筋がもっとも長かった。

B. 毛づくろい行動

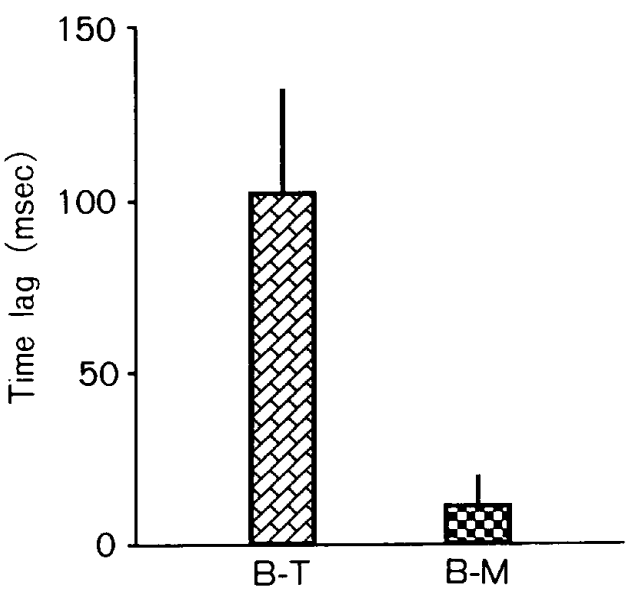

Fig. 6 Time lag (mean \pm S. D.) of rhythmical bursts between one muscle and other muscle during chewing.

B-T : Experimental group of buccinator and tongue muscles. B-M : Experimental group of buccinator and masseter muscles.

Fig. 8 は毛づくろい行動時の筋電図である，毛づく ろい行動時には煩筋, 舌筋, 咬筋にその毛づくろいの䇢 所により，様々なパターンの筋電図が認められた．手を なめる時には煩筋，舌筋のいずれにもりズミカルな放電 が認められた（図の G 1)，後肢の毛づくろいでは煩筋 に持続的な放電，舌筋にリズミカルな放電が認められた (G 2). また，毛づくろい時に咬筋の放電を認めるこ 
とは少なかったが，咀嚼時と異なり煩筋と咬筋にサイク ルの異なる放電が認められた（G 3).

C. 探查行動時

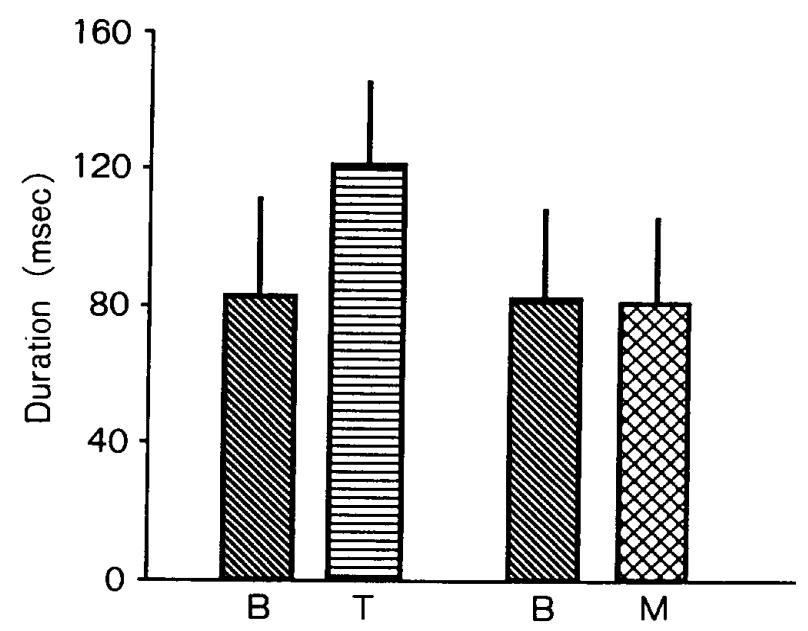

Fig. 7 Duration (mean \pm S. D.) of rhythmical bursts during chewing.

Others are the same as Fig. 3.
Fig. 9 に探查行動時の筋電図を示す。探查行動時に はその行動の多彩さから様々なパターンの筋電図が発生 した.

煩筋には持続的な放電, 舌筋にはリズミカルな放電が 認められるパターン（図の E 1), 煩筋には摄食行動時 とは異なる短いサイクルの放電, 舌筋には放電が途切れ るパターン，咬筋には放電がほ之んよ゙認められないパ ターン (E 2), 煩筋には持続的な放電, 舌筋之咬筋に は放電がほとんど認められないパターン（E 3) などが あった。

D. 安静時

Fig. 10 に安静時の筋電図を示す.ラットがほとんど 行動しない場合では煩筋, 舌筋, 咬筋に放電を認めた ケースは少なかったが, 頉筋のみにリズミカルで摄食行 動時よりサイクルがやや長い放電が認められるパターン （図の R 1)，煩筋には R 1 と同じような放電が認めら れる場合に，咬筋に短いサイクルのリズミカルな放電が 短時間出現するときには, 煩筋にも同じサイクルの放電 が同期しているパターン（R 2)，ラットは眠っている ように観察される時に煩筋には持続的な放電が，舌筋に

G1

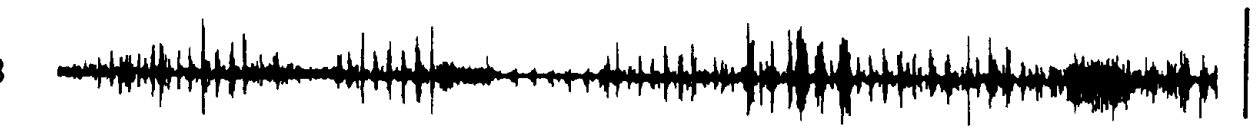

$T$
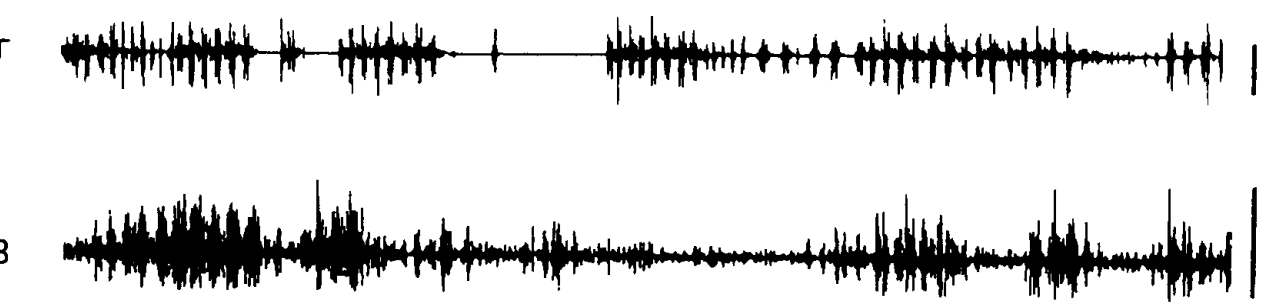

G2

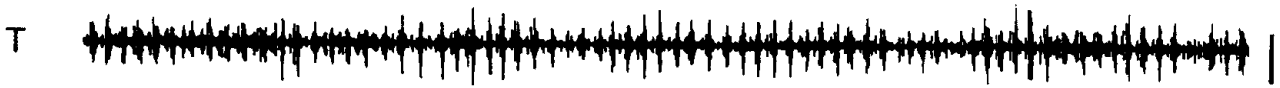

G3
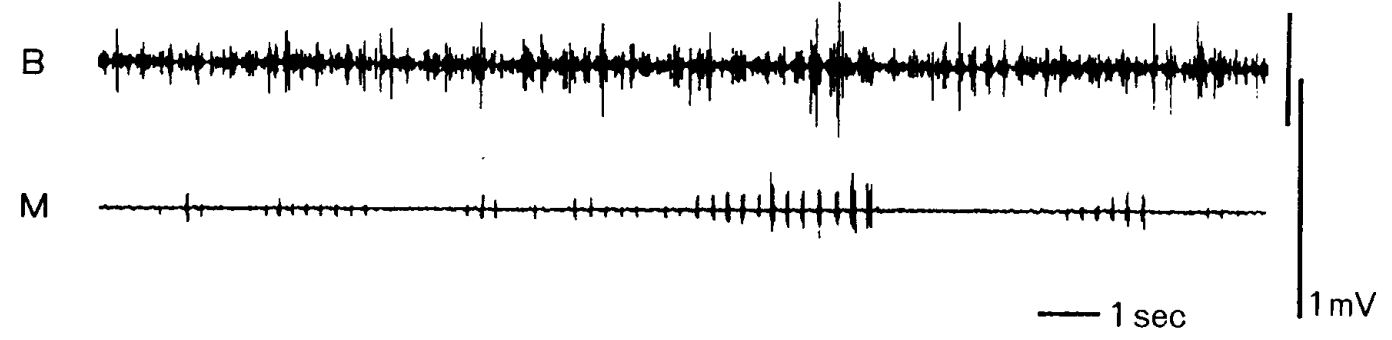

Fig. 8 EMG patterns during grooming.

G 1, G 2 and G 3 indicate three types of the EMG pattern. Others are the same as Fig. 3. 


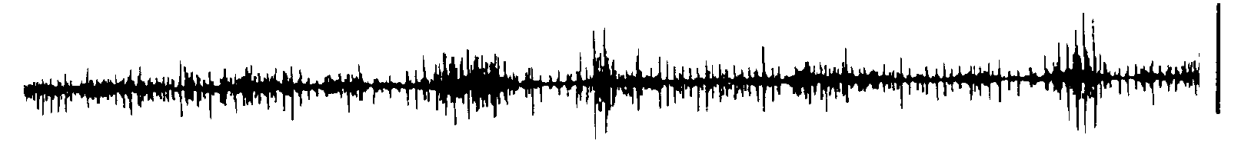

E1

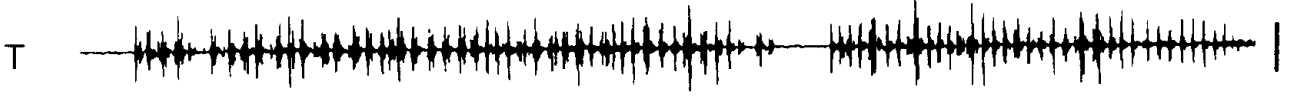

$B$

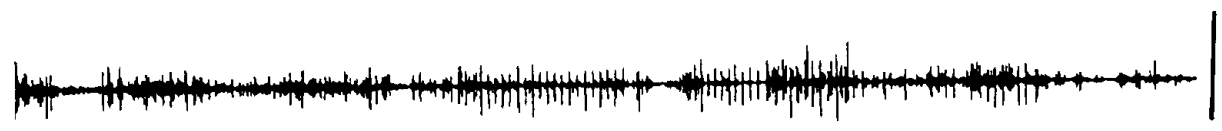

E2

$\mathrm{T}$

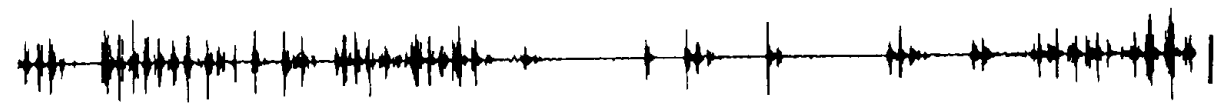

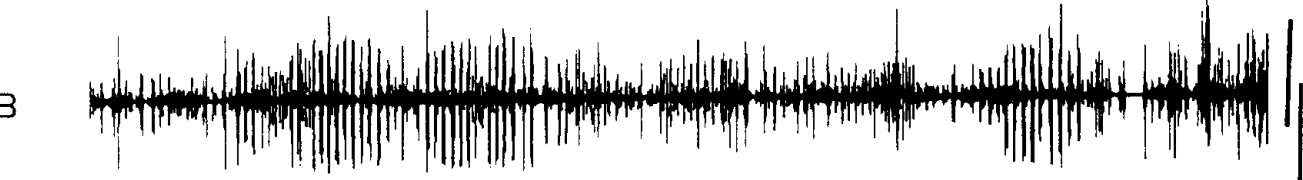

M

B

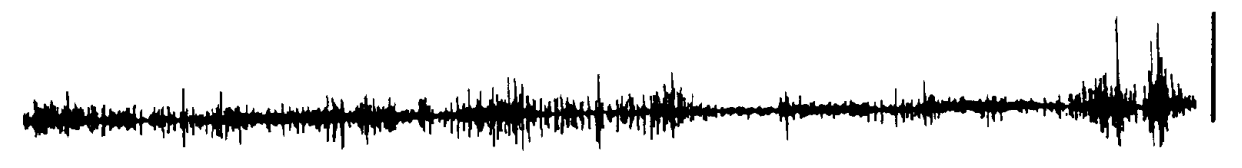

E3

T

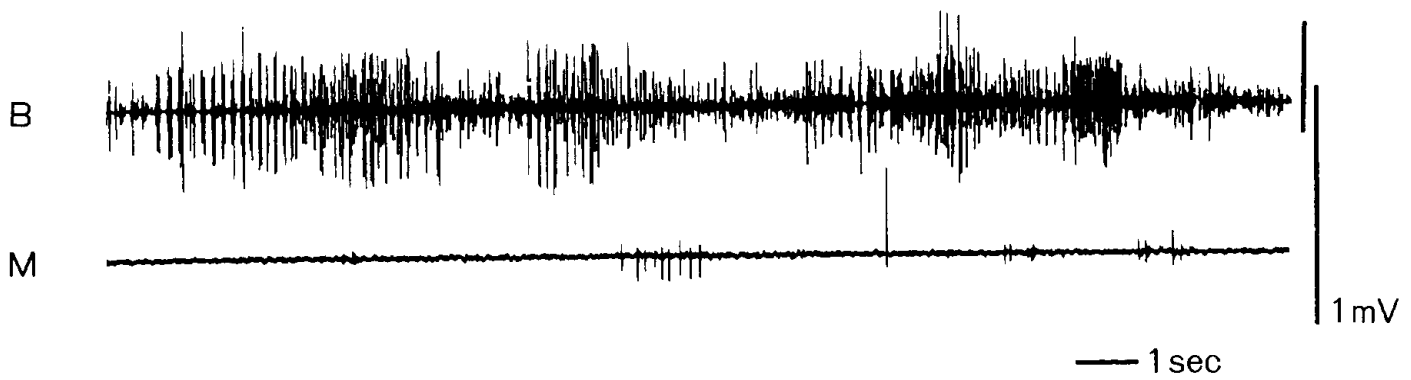

Fig. 9 EMG patterns during exploring.

E 1, E 2 and E 3 indicate three types of the EMG pattern. Others are the same as Fig. 3.

はリズミカルな放電が認められるパターン (R 3$)$, ラットがわずかに顔を動かした時, 煩筋と舌筋に連動し た短い放電が単発的に認められるパターン（R 4) など があった。

II. 積分值

それぞれの箭の䘞食行動時の積分值を 100 とし, 毛づ くろい行動, 探查行動, 安静時の筋活動量を比較検討し
た. Fig. 11 に種々の行動時の筋活動量の相対値を示す.

A. 摂食行動

煩筋一舌筋群では煩筋で $100 \pm 24.4$ ，舌筋で $100 \pm$ 16.5 であった（図の A). 煩筋一咬箭群では煩筋で 100 \pm 41.8 ，咬筋で $100 \pm 30.8$ であった（B）.

B. 毛づくろい行動

煩筋一舌筋群では煩筋で $97.6 \pm 82.6$, 舌筋で $53.8 \pm$ 
R1

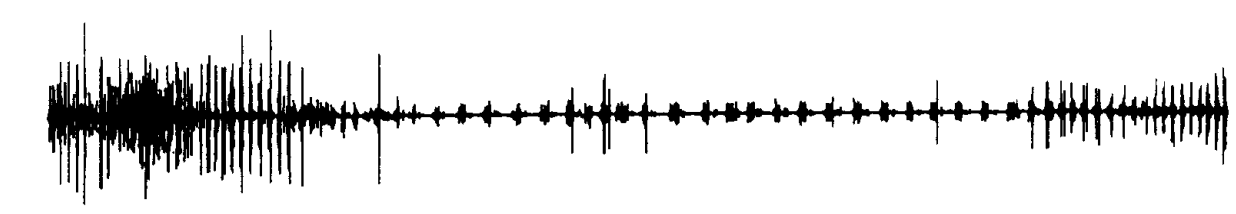

M

B

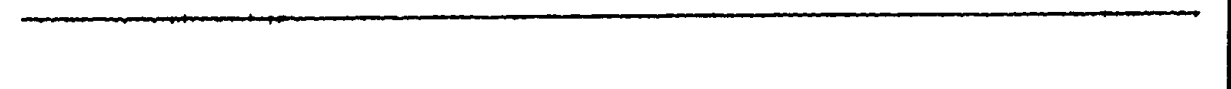

B

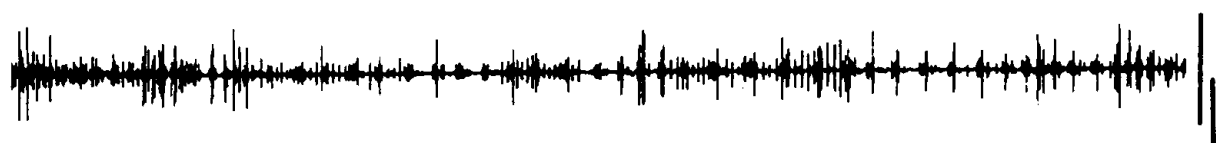

R2

M

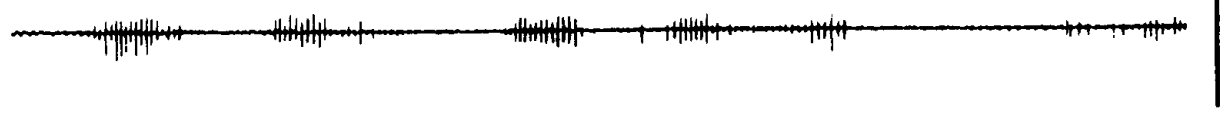

B

R3

T

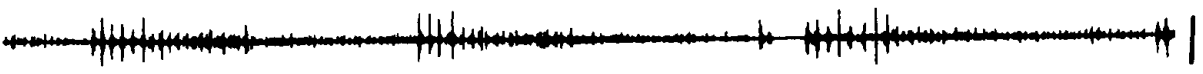

B

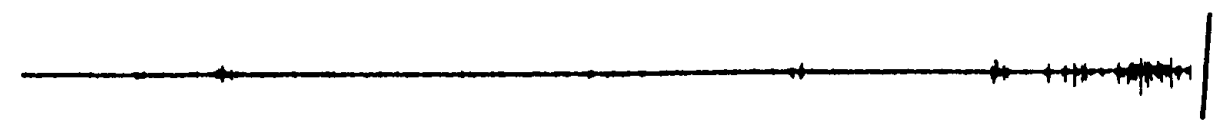

R4

T

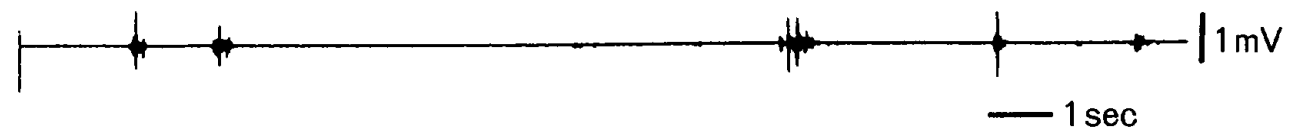

Fig. 10 EMG patterns during resting.

$\mathrm{R} 1, \mathrm{R} 2, \mathrm{R} 3$ and R 4 indicate four types of the EMG pattern. Others are the same as Fig. 3.

46.8 であった（図の A)．顂筋一咬筋群では煩筋で 100.0 \pm 41.0 ，咬筋で $48.8 \pm 32.2$ であった（B)．毛づくろい 時の㚘筋の筋活動量は, 摂食行動時とほとんど同じで あったが, 咬筋, 舌筋の活動量は約 $1 / 2$ に低下してい た. また，その筋活動量はばらつきの大きいものであっ た.

\section{C. 探查行動}

頪筋-舌筋群では煩筋で $107.3 \pm 39.0$, 舌筋で $46.2 \pm$ 23.0 であった（図の A)．煩筋一咬筋群では煩筋で 128.0
士66.2，咬筋で $36.2 \pm 32.3$ であった（B）．探查行動時 の煩筋の筋活動量は, 摄食行動時より幾分大きかった が，舌筋，咬筋では大きく低下していた。

\section{D. 安静時}

煩筋-舌筋群では煩筋で $48.6 \pm 20.3$, 舌筋で $22.5 \pm$ 19.0 であった（図の A)．煩筋一晈筋群では煩筋で 30.7 \pm 18.6 ，咬筋で $30.8 \pm 22.4$ であった（B)．安静時の煩 筋, 舌筋, 咬筋の筋活動量は摂食行動時上り大きく低下 していた. 


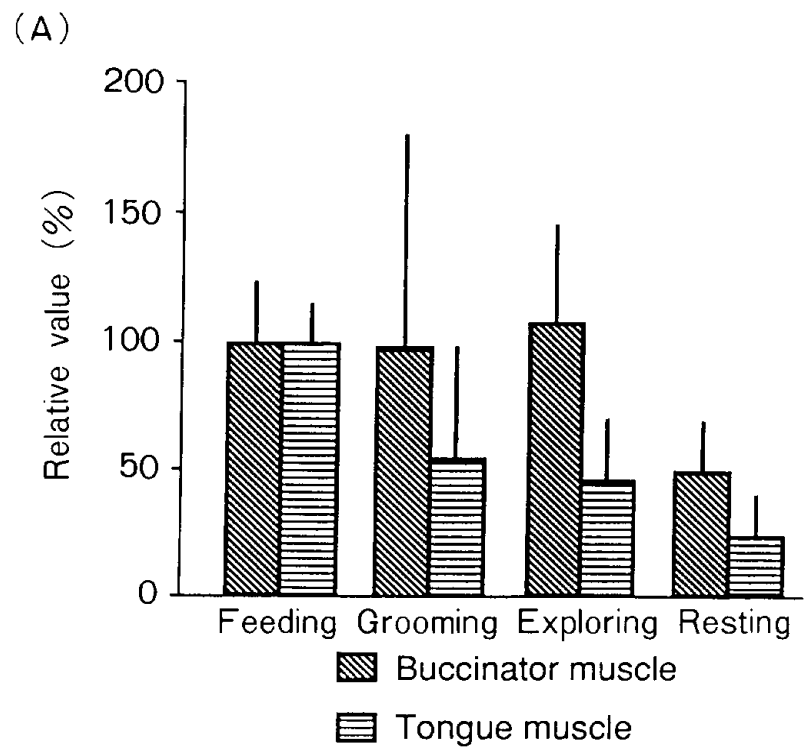

(B)

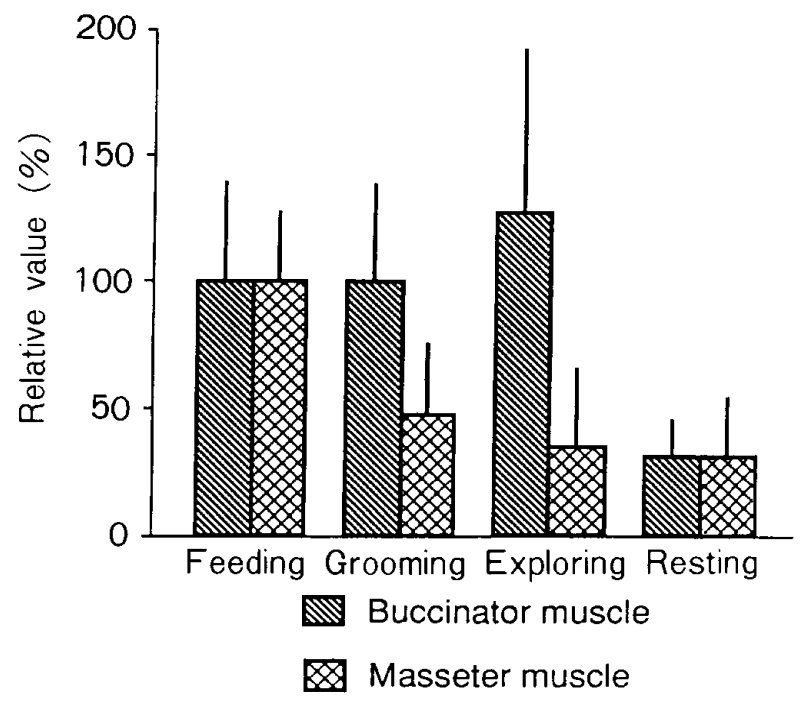

Fig. 11 Comparative magnitude (mean \pm S. D.) of the integrated EMGs in three muscles during feeding, grooming, exploring and resting.

(A); Experimental group of buccinator muscle and tongue muscle. (B); Experimental group of buccinator muscle and masseter muscle.

Each magnitude is showed with the relative value when the magnitude of integrated EMG in each muscle during feeding is indicated as $100 \%$.

\section{考 察}

I 、記録方法

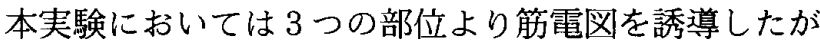
各部の筋電図が混入しないことが絶対条件である，その
ため電極を双極誘導とした．また，煩筋と咬筋とは距離 があり，間に煩骨もあって隔絶されている．実際の記録 を見ても咀罚時の煩筋から導出した放電は，咬筋のそれ より約 $10 \mathrm{msec}$ 早期に発生したこ之，また咬筋に振幅 の大きな放電が発生している時でむ煩筋にはそれに対応 するような放電は認められなかったことなどから，煩筋 の筋電図には咬筋の筋電図は混入していないことが確認 された。

\section{II. 種々の行動時の筋電図}

咀嚼時に下顎はリズミカルな運動を起こす。このリズ ム形成については電気生理学的に多くの研究が行われて きた. Sumi $(1970)^{12)}$, Dellow 弓 $(1971)^{13\rangle}$, Nakamura ら $(1976)^{14\rangle}$ ，榎本 $(1982)^{15\rangle}$ は，筋弛緩薬の投与に よって動物の非動化を行い末梢からの感覚入力がない状 態で皮質咀嚼野を連続電気刺激した場合，咀礵筋支配運 動神経にはリズミカルな遠心性発射が誘発されることな ぞから, 延髅網様体に咀嚼リズム形成器が存在すること を明らかにしている。

また, 浅原ら (1989) ${ }^{16)}$ が脳幹の咀嚼りズム形成器部 位から顔面神経核運動ニューロンへの投射があることを 報告していることから，顔面筋も咀緭時には咀嚼リズム 形成器の支配のもとに活動すると考えられる.

一方, 舌運動のリズム形成については, Sahara ら

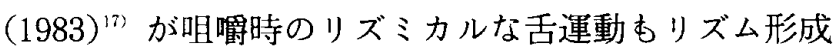
器によってっくられることを報告している．さらに橋本 ら (1985) $)^{18\rangle}$ は舌下神経核に投射するニューロンが延䯣 網様体に存在することを認め, 舌運動のリズム形成器は 延䯣網様体にあるとしている.

これらのことをもとに，同じリズム形成器に支配され ている顔面筋や咀緭筋，また舌筋がどのように協調して 活動をしているかを調べた。

本実験の頓筋-舌筋群，頓筋一咬筋群のいずれでも咀嚼 時のリズミカルな放電のサイクルは，各筋で約 220 msec とほぼ一致し，かつその活動は連動していた。こ れは，咀緭時には煩筋と舌筋および煩筋と咬筋の間には 対応関係があり，これらの筋は同じサイクルで活動し， 連動していることがわかった．また，咀嚼時のリズミカ ルな放電の位相差は，煩筋と舌筋の間で約 $100 \mathrm{msec}$, 煩筋と咬筋の間で約 $10 \mathrm{msec}$ であった，煩筋之咬筋の 間の位相差は咀夁サイクルの約 $1 / 2$ と大きく, 煩筋と 咬筋の間の位相差は逆に約 $1 / 20$ 之極めて小さかった。 その放電持続時間がいずれの筋でも数 $10 \mathrm{msec}$ である ことを考慮すると，煩筋と咬筋とではリズミカルな放電 はほぼ同期しており，また煩筋と舌筋とでは明らかに位 
相差があることがわかる.

前述の報告のように咀㘉時の顔面筋, 咀魦筋, 舌筋活 動のリズム形成器は延随網様体に存在することが明らか である，本実験では煩筋と咬筋の活動にはほとんど位相 差がなかったのに対し舌筋では大きな位相差が認められ た.このことからリズム形成器から顔面神経運動核およ び三叉神経運動核までの伝達機序と舌下神経運動核まで の伝達機序に大きな差異があると考えられる.

咀嚼時のリズミカルな放電の持続時間は煩筋, 咬笳で 約 $80 \mathrm{msec}$ であったのに対し, 舌筋では約 $120 \mathrm{msec}$ と 顕著に長かった。 また, 舌筋の放電持続時間は咬筋より 長いにもかかわらず，両者のサイクルはほとんど変わら なかった．舌筋の放電持続時間が長かったのは，舌が多 くの筋束から構築され，とくに内舌筋には上下縦舌筋， 横舌筋, 垂直舌筋があり, それらが複雑に交叉して ${ }^{6,7)}$, 精妙な運動を行っていることと関係があると考えられ る.

Thomas ら (1983) ${ }^{199}$ は餌の硬さや大きさによって ラット咬筋の咀㘉時のリズミカルな放電持続時間が変化 すると述へ，平川ら $(1990)^{20)}$ 屯摄食時の放電持続時間 の変化は食塊の粉研による飼料の性状の変化によるすの であるとしている，本実験ではこのことが関係してリズ ミカルな放電の持続時間の標準偏差が大きくなったもの と考えられる.

切䨤部咬断音時にみられる筋電図の特徵として煩筋に リズミカルでない放電が，舌筋と咬筋には振幅の小さな 放電が認められた．これらの放電はかじった飼料は䫕と 舌の協調した運動で臼歯へ送られるとWeijes (1975) ${ }^{3}$ が報告しているように，かじり取った食物を臼歯部に運 び，保持することに関係していると考えられる.

一連の摂食行動の中では咀㘉終了後の筋電図にも煩筋 には持続的な放電が, 舌筋, 咬筋にはリズミカルな放電 が発生する特徴が認められた。この筋電図のパターンは ロを動かし，咬合している時に顔を動かしたり周りを嗅 いだり，次の餉を探ったりしていた場合に認められた。 この時, ラットは口腔内では食物残渣を移動させている のではないかと考える.

毛づくろい時の筋電龱は毛づくろいの場所により種々 のパターンが認められた。

毛づくろい時に認められるリズミカルな放電について は，一定のサイクルを有する放電が長く続かなかったた め本実験ではサイクルの測定を行わなかった。しかし， そのサイクルは咀礵時のもの之は異なっていたようであ る.
探查行動は毛づくろい以上に多彩な行動であるため, 種々のパターンがあり，これを分類することは容易では なかった. そこで細かく分類することを避け，大きく 3 つのパターンに分けた，すなわち，煩筋には持続的な放 電，舌筋にはリズミカルな放電が認められるパターン， 煩筋には摄食行動時とは異なる短いサイクルの放電, 舌 筋之咬筋には放電がほとんど認められないパターン, 煩 筋には持続的な放電, 舌筋と咬筋には放電がほとんど認 められないパターンである。このうち，煩筋にリズミカ ルな放電が認められる時では, ラットは匂い行動をして いるように観察された.

安静時にむ筋電図が記録されたが時間的にはかなり短 かった。しかし，ラットが眠っているように観察される 時にも時間的には短くとも煩筋, 舌筋に筋活動か認めら れ, 㛲筋, 舌筋は安静時にもしばしば活動することがわ かった．これは, 安静時にはほとんど働かない咬筋とは 異なっていた。

III. 積分値

筋電図の積分值から算定された筋活動量は爽筋では, 摄食行動時を 100 とすると, 毛づくろい行動時はほとん ど変わらず, 探査行動時は増加傾向を示し, 安静時は顕 著に隇少した，舌筋と咬筋では，㨟食行動時を 100 とす ると, 毛づくろい行動, 探查行動時, 安静時でともに減 少した。

摂食行動時には煩筋, 舌筋, 咬筋のいずれあ筋活動量 が大きかった，安静時では頓筋，舌箭，咬筋はいずれも 摄食行動時より筋活動量が咸少した。 また，毛づくろい 行動, 探查行動では煩筋は舌筋, 咬筋と異なる傾向を示 した. すなわち，煩筋は毛づくろい行動，探查行動時に も筋活動量が大きく，摂食行動時と同じか，少し堌加し ていたが, 舌筋, 咬筋では約 $1 / 2$ に減少していた。

舌筋が種々な㗢きや複雑な動きをすることは広く知ら れているが，このことは前述の筋電図パターンにもよく 表われている. しかしながら, 舌筋の筋活動量はやはり 摂食行動時に大きかった。一方, 咬筋は安静時を除き, 種々の行動で筋活動量に差はないことがわかった.

\section{結論}

本実験は顔面筋である頓筋，咀嚼時に主動的役割を果 たす咬筋，咀畄時に食物を歯列間に運ぶ舌筋の各行動時 の筋活動の特徽，およびそれぞれの筋活動がどのような 関係にあるかを調べた．その結果を要約すると以下のよ うである.

1）摄食行動, 毛づくろい行動, 探査行動および安静 
時において煩筋，舌筋，咬筋のいずれにもリズミカルな 箭活動が認められた。

2）摂食行動時には煩筋と舌筋，および煩筋と咬筋に はそれぞれ連動したりズミカルな放電が認められた。こ の放電サイクルは煩筋，舌筋，咬筋ともに約 $220 \mathrm{msec}$ でほぼ一致していた。

3）摄食行動時のリズミカルな放電は煩筋と舌筋では

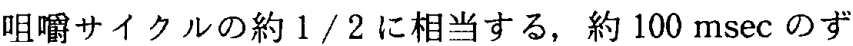
れがあった。一方，頖筋と咬筋の間のずれは約 $10 \mathrm{msec}$ でほぼ同期していることがわかった。

4）咀嚼時のリズミカルな放電の持続時間は舌筋で あっと屯長く，煩筋と咬筋ではほとんど同じであった。

5 ）煩筋の筋活動量は摄食行動，毛づくろい行動，探 查行動ではほとんよ゙変わらず，安静時ではそれらの行動 時の約 $1 / 2$ に減少した。舌筋では摄食行動時に比べ, 毛づくろい行動, 探査行動時では約 $1 / 2$, 安静時では 約 $1 / 5$ に減少した。咬筋の筋活動量は毛づくろい行 動, 探査行動, 安静時では摃食行動時より隇少した。

以上のことから，1）頓筋と咬筋，舌筋の活動には時 間的な差異があることから，リズム形成器からの伝達機 構に大きな差異があると考えられる，2）咬筋と舌筋は 摄食行動時に筋活動量が特に大きいのに対し，煩筋は安 静時以外の諸行動時にあ筋活動量にほとんど差異がな く，種々の行動に参加していることがわかった.

稿を終えるにあたり, 本研究に終始御想切なる御指導 々御校閲を睗った恩師, 西 正勝教授ならびに九州歯科 大学生理学講座中原 敏教授に対し, 深甚なる感謝の意 を表するとともに，数多くの御教示をいただきました九 州歯科大学生理学講座平川輝行博士に感謝致します。 ま た，終始ご協力いただきました歯科麻酔学講座および生 理学講座の皆様に厚く御礼申し上げます.最後に, 終始種 々の面で私を支えて下さいました方々に感謝致します。

なお本論文の要旨の一部は, 第 34 回歯科基礎医学会 総会（平成 4 年 10 月 $14 ， 15$ 日）において発表した。

\section{引用文献}

1) 谷津利夫, 佐藤 享：七卜煩筋の解剖学的研究 1, 肉眼 的観察. 㐘学 $76(3): 516-517,1988$.

2) 谷津利夫, 佐藤 厳, 佐藤 享: 七上煩筋の解剖学的研究 一筋線維構成に上る解析. 解剖学雑誌 $64(4): 386$, 1989.

3) Weijes, W. A. : Mandibular movement of the albino rat during feeding. J. Morph. 145: 107-124, 1975.
4 ) 戸村善明：X 線テレビ映画法による咀射時の舌運動につ いて 1. 矢状方向からの観察. 菌科学報 79（12）: $2271-2303, \quad 1979$

5) 戸村善明：X 線テレビ映画法による咀嚁時の舌運動につ いて 2. 前額方向加らの観察. 苗科学報 $80(1): 33$ $-51,1980$.

6) 河村洋二郎：新編口谐生理学上巻. 永末書店, 京都, $1956,100-104,190-121$.

7 ）上條雍彦：小口腔解部学，アナトーム社，東京，1962，66 $-71$.

8）害田金次郎：解剖学入門一咀灀システム解明への道. 日本 歯科評論社, 東京, $1988,50-66$.

9 ) 成田紀之：㴿・舌運動制御にかかわる咀簙筋および舌筋固 有受容感覚ニューロンの中枢分布一第 $\mathrm{I}$ 報. 咀噯筋固有受 容感覚二ューロンの分布一。病誌 $54(2): 365-386$, 1987.

10）成田紀之：䪽・舌運動制御にかかわる咀嘌筋および舌筋固 有受容感覚ニューロンの中枢分布一第 II 報. 舌筋固有受容 感覚ニューロンの分布一. 口病誌 $54(2): 387-403$, 1987.

11) Hutson, K. A. and Masterton, R. B.: The sensory contribution of a single vibrissa's cortical barrel. J. Neurophy. 56 (4) : 1196-1223, 1986.

12) Sumi, T. : Activity single hypoglossal fibers during cortically induced swallowing and chewing in rabbits. Pflügers Arch. $314: 329-346,1970$.

13) Dellow, P. G. and Lund, J. P. : Evidence for central timing of rhythmical mastication. J. Physiol. $215: 1$ $-13,1971$.

14) Nakamura, Y., Kubo, Y., Nozaki, S. and Takagi, M. : Cortically induced masticatory rhythm and its modification by tonic peripheral inputs in immobilized cats. Bull. Tokyo Med. Dent. Univ. 23: $101-107$, 1976.

15）榎本純男：大脳皮質による咀啷りズムの中枢性形成におけ る内側延咀網梯体二ューロンの役割。口病誌 $49: 18$ 30,1982

16）浅原俊弘，西村嘉洋，田中 任：ネコの咀嚼りズム形成部 位により顔面神経核運動ニューロンに対する投射様式. 三 重医学 $32: 437-442,1989$.

17) Sahara, Y., Katoh, M. and Nakamura, Y. : Nature of cortically induced masticatory activity of hypoglossal motoneurons in cats. J. Physiol. Soc. Japan, 45 (8) : 428, 1983

18）橋本信行，佐原資謹，中村嘉男：舌下神経核に投射する延 䯣網様体二ューロンの皮質咀絪野連続刺激に対する応答様 式. 菌基礎誌 27 (補冊)：166，1985.

19) Thomas, N. R. and Peyton, S. C.: An electromyographyic study of mastication in the freelymoving rat. Arch Oral Biol. 28 (10): $939-945,1983$.

20）平川輝行，本田栄子，原厳，中村修一，中原敏：ラッ 卜の頻運動を伴う日常行動の筋電図学的研究. 九州菌会誌 44 (5) : 788-804, 1990. 